УДК 331.464.3

Канд. техн. наук В.Г. Брусенцов, д-р техн. наук М.И. Ворожбиян, стари. препод. И.И. Бугайченко, ассист. О.В. Брусенцов (УкрГАЖТ), канд. биол. наук Л.В. Аладышева (НИИПМ)

\title{
ЛИЧНОСТНЫЕ ОСОБЕННОСТИ КАК ФАКТОР РАБОТОСПОСОБНОСТИ ЖЕЛЕЗНОДОРОЖНЫХ ОПЕРАТОРОВ
}

Введение. Безопасность движения на железнодорожном транспорте сегодня определяет «человеческий фактор», на долю которого приходится около $80 \%$ причин и предпосылок транспортных происшествий [1]. Сегодня этот термин подразумевает, в решающей мере, профессиональную надежность железнодорожных операторов - работников локомотивных бригад и оперативного диспетчерского персонала. Следовательно, важнейшим условием поддержания безопасности должен быть контроль их профессиональной надежности.

Анализ последних публикаций. Одной из важнейших составляющих профессиональной надежности является работоспособность, которая определяется как «способность поддержания организма в оптимальном рабочем состоянии для максимизации вносимого вклада в результат рабочей системы, благодаря физическому или информационному труду» [2]. Следовательно, проблема контроля уровня их работоспособности является более чем актуальной.

При организации такого контроля большое значение имеет, на какой основе он производится - на основе среднестатистической или индивидуальной нормы. В последнем варианте контроль может быть существенно эффективнее [3].

При этом встает вопрос об основе индивидуального подхода, для этого используют конституциональные, психофизиологические, нейрофизиологические и другие особенности человека. Одним из широко применяемых в настоящее время является изучение личностных особенностей, для чего применяется ряд тестов.

Основная часть. Для оценки влияния личностных особенностей на такую важную составляющую работоспособности, как уровень здоровья железнодорожных операторов, было проведено экспериментальное исследование. Большая группа работников была протестирована по тесту Кеттелла и у них был определен показатель «Уровень физического состояния» (УФС) [4]. Этот показатель, имея высокую корреляцию с велоэргометрическим стресс-тестом, занимает мало времени и не требует сложных медицинских процедур.

Для учета гендерных различий, корреляционный анализ полученных данных проводился отдельно для мужчин и женщин. Были получены корреляционные уравнения, выявляющие значимые связи 
УФС с рядом личностных характеристик, при этом были обнаружены заметные гендерные различия.

Для мужчин:

$\mathrm{У} \Phi \mathrm{C}=0,4491+0,0011 \cdot \mathrm{A}+0,0023 \cdot \mathrm{E}-$ $-0,0021 \cdot \mathrm{F}-0,0014 \cdot \mathrm{H}+0,0013 \cdot \mathrm{M}+0,0010$. $\cdot \mathrm{N}+0,0022 \cdot \mathrm{O}-0,0022 \cdot \mathrm{Q} 1+0,0008 \cdot \mathrm{Q}_{2}$

Для женщин:

$\mathrm{УФC}=0,4905-0,0016 \cdot \mathrm{B}-0,0038 \cdot \mathrm{C}+$ $+0,0008 \cdot \mathrm{E}-0,0017 \cdot \mathrm{F}+0,0008 \cdot \mathrm{G}+0,0015 \cdot$ $\cdot \mathrm{H}+0,0008 \cdot \mathrm{I}+0,0003 \cdot \mathrm{L}+0,0019 \cdot \mathrm{N}-$ $-0,0018 \cdot \mathrm{O}+0,0087 \cdot \mathrm{Q}_{1}+0,0014 \cdot \mathrm{Q}_{2}+$ $+0,0002 \cdot \mathrm{Q}_{3}+0,0014 \cdot \mathrm{Q} 4-0,0005 \cdot \mathrm{MD}$

Результаты показали, что у мужчин УФС оказался связанным только с фактором $\mathrm{Q}_{1}$, при высоких оценках которого человек характеризуется как критически настроенный, имеющий интеллектуальные интересы. Чем больше выражены указанные черты, тем выше вероятность наличия у данного человека высокого уровня УФС, что согласуется с данными о достаточно тесной связи уровня интеллекта с уровнем здоровья, полученными в Англии [5]. Таким образом, высокий интеллект позволяет иметь более высокий уровень здоровья.

У женщин значимую корреляцию с УФС показали факторы - Q 3 , M, MD, F, Q4:

- на уровне $\mathrm{p}=0,54$ фактор $\mathrm{Q}_{3}$ «высокий самоконтроль - низкий самоконтроль». При высоких оценках, человек имеет развитый самоконтроль, точность выполнения социальных требований. При низких оценках наблюдаются недисциплинированность, внутренняя конфликтность представлений о себе;

- на уровне $\mathrm{p}=0,52$ фактор $\mathrm{M}$ «мечтательность - практичность», высокая оценка указывает на развитое воображение, ориентация на свой внутренний мир, высокий творческий потенциал человека;

- на уровне $\mathrm{p}=0,44$ фактор MD, характеризующий адекватность самооценки. При этом, чем сильнее женщина склонна переоценивать свои возможности, тем более низкий уровень УФС она имеет;

- на уровне $\mathrm{p}=0,4$ фактор $\mathrm{F}$ «сдержанность - экспрессивность». При высоких оценках по этому фактору человек энергичный, жизнерадостный;

- на уровне $\mathrm{p}=0,37$ фактор Q4 «расслабленность - напряженность». Высокая оценка свидетельствует о напряженности, фрустрированности.

Такое сочетание позволяет утверждать, что более высокому уровню УФС у женщин способствует наличие таких личностных особенностей, как:

- наличие развитого самоконтроля, высокий творческий потенциал;

- склонность скорее недооценивать свои возможности, чем их переоценивать;

- жизнерадостность, энергичность, динамичность.

Выводы. Выявлены связи уровня физического состояния и личностных особенностей у железнодорожных операторов, т.е. наличие определенных личностных особенностей может способствовать либо противодействовать сохранению здоровья, при этом наблюдаются выраженные гендерные различия. Знание этих зависимостей позволяет повысить эффективность контроля уровня профессиональной надежности железнодорожных операторов.

\section{Список литературы}

1. Савченко, С.В. Оценка уровня безопасности движения поездов и методы ее повышения [Текст] / С.В. Савченко // Перспективи впровадження технічних засобів безпеки руху на залізницях України. - Хмельник, 2010. - С. 21-25.

2. http://www.up-pro.ru/encyclopedia/rabotosposobnost-cheloveka.html. 
3. Самсонкин, В.Н. Теоретические основы контроля человеческого фактора в человекомашинных системах на железнодорожном транспорте [Текст]: дис. ... д-р техн. наук: 05.22.08 «Эксплуатация железнодорожного транспорта» / В.Н. Самсонкин. - Харьков, 1997. $-412 \mathrm{c}$.

4. Пирогова, Е.А. Влияние физических упражнений на работоспособность и здоровье человека [Текст] / Е.А. Пирогова, Л.Я. Иващенко, Н.П. Страпко. - М.: «Здоровье», 1986. $150 \mathrm{c}$.

5. Ученые нашли связь между интеллектом и здоровьем [Электронный ресурс] Режим доступа: http://www.utro.ru/articles/2004/07/19/331251.shtml.

Ключевые слова: человек-оператор, профессиональная надежность, личностные особенности, индивидуальная норма, контроль.

\section{Аннотации}

Выявлены и формализованы зависимости уровня физического состояния от личностных особенностей у железнодорожных операторов. При этом наблюдаются выраженные гендерные различия. Знание этих зависимостей позволяет повысить эффективность контроля уровня профессиональной надежности железнодорожных операторов.

Виявлено i формалізовано залежності рівня фізичного стану від особистісних особливостей у залізничних операторів. При цьому спостерігаються виражені гендерні відмінності. Знання цих залежностей дозволяє підвищити ефективність контролю рівня професійної надійності залізничних операторів.

The dependence of physical conditions' level on railway operator's personal characteristics have been identified and formalized in this paper. Expressive gender distinctions can be observed. Knowledge about these dependences allows to increase the efficiency of controlling the level of railway operators' professional reliability. 